\title{
Effect of Ultrasonic Treatment on Buffalo Milk Homogenization and Numbers of Bacteria
}

\author{
As aad Rehman Saeed Al-Hilphy, Alaa Kareem Niamah", Ammar B. Al-Temimi \\ Department of Food Science, College of Agriculture, University of Basrah, Basrah, Iraq
}

\begin{abstract}
The effect of ultrasonic treatment on milk homogenization and numbers of bacterial were studied. The results showed that ultrasound treatments with high power had an important effect on milk homogenization. The lowest homogenization indices (high efficiency) were 2 and $3 \%$ at 430 and $338 \mathrm{~W}$ respectivily. The homogenization index was reduced with increasing time of ho mogenization with ultrasonic treatments. The mean D-values were 6.47 and 5.49 min. for ultrasonic treatments of 338 and $430 \mathrm{~W}$ respectively.
\end{abstract}

Keywo rds Buffalo Milk, Bacteria, Homogenization, Ultrasonic

\section{Introduction}

Utilization of high intensity ultrasound in food technology and biotechnology is in the sense of this progressive technology usage on most usable processes in food industry. Those include mixing, drying, homogenization, crystallization, grinding and many other operations. High intensity ultrasound is capable to change physical and chemical characteristics of treated materials [1].

Ultrasound is of great investment in food processing for many reasons[2]. This technique can be generally used in systems which are liquids and can be defined as waves with high frequency[3]. High amplitude of ultra sound and longer exposure time ensure greatest effect on degree of homogenization. The mechanisms which are contributing to fat globules disruption is known as the capillary wave's mechanis ms. Decreasing of fat globules is possible only if the diameter of fat globules is significantly larger than the oscillation wave length and for oil - water systems is approximately $10 \mu \mathrm{m}$. Cavitation is the most accepted mechanis $\mathrm{m}$ for ultrasound emulsification. This mechanism is based on the implosion bubbles which produce powered shock waves in the milk surrounding the ultrasonic probe and jets of high velocity. This micro jet effectively causes fat globules disruption[4]. Ultrasound has various applications in the food industry, including killing or inhibiting bacteria.

Historically, the effectiveness of low intensity ultrasound in inactivating bacterial cells has been limited by the

* Corresponding author:

alaakareem2002@hotmail.com (Alaa Kareem Niamah)

Published online at http://journal.sapub.org/food

Copyright (C) 2012 Scientific \& Academic Publishing. All Rights Reserved protection afforded to the organisms by the food environment. Recently, however, systems with high output of ultrasonic energy at low frequency have greatly increased the lethal effect on bacteria[5]. In general, inactivation of the cells is more pronounced at an elevated power level and as the processing time increases.

One of non traditional types of milk processing is ultrasonic processing. At present time, ultrasonic devices for homogenization are used at milk processing[7]. Ultrasound treatment with high amplitude (power) hands an impotent effect on milk homogenization compared to conventional homogenization. As exposure time and power levels increase homogenization efficiency also rise. The highest homogenization efficiency and the smallest fat globule diameter are 3.22 and $0.725 \mu \mathrm{m}$ at power level 100 $(450 \mathrm{~W})$ for $10 \mathrm{~min}$. respectively. The fat globule diameters at power level of $40(180 \mathrm{~W})$ for $10 \mathrm{~min}$ are similar to those of conventional homogenization [8].

Increase of the power (100Watt) lead to increase of degree of stated homogenization, and decrease in size of fat globules in soybean milk[9]. Homogenization must always be sufficiently efficient to prevent creaming. The result can be checked by determining the homogenization index. The index for homogenized milk should be in the range of 1 to 10. The effect of homogenization on the physical structure of milk has many advantages: Smaller fat globules leading to no cream-line formation, whiter and more appetizing color, reduced sensitivity to fat oxidation, more full-bodied flavor, better mouth feel and better stability of cultured milk products[10]. Ultrasound treatment with high amplitude (power) has an important effect on milk homogenization compared with conventional homogenization and the best homogenization and the smallest fat globule diameter $(0.725 \mu \mathrm{m})$ are obtained at a power level of 10 minutes[8]. The objective of our study was to investigate the effect of 
different of ultrasound treatments on buffalo milk homogenization and numbers of bacterial cells during different times to compare these with conventional homogenization

\section{Materails and Methods}

\subsection{Materials}

Buffalo milk was obtained from the dairy farm at Karmt Ali-Basrah city, Iraq.

\subsubsection{Used Cultural Media}

Commercially media were used for total bacterial count, coliform bacteria and staphylococci. The media used for bacteriological analysis were nutrient agar, MacConkey agar and mannitol Salt agar (Hi-Media, India).

\subsection{Methods}

\subsubsection{Conventional Ho mogenization}

The conventional homogenizer (Kirchfeld-Germany) was used to homogenize the milk under a high pressure of 200 bar at $55^{\circ} \mathrm{C}$.

\subsubsection{Ultrasonic Ho mogenization}

An Ultrasonic homogenizer (Son prep 150 MSE, Korea) equipped with $0.5 \mathrm{~cm}$ diameter tip and working at a constant frequency $(28 \mathrm{kHz})$ was used to homogenize 150 $\mathrm{ml}$ of buffalo milk for each treatment. The ultrasound probe was immersed in to the milk at depth of approximately $4 \mathrm{~cm}$. The experiment was carried out using different power levels. Exposure times were 5, 10 and $15 \mathrm{~min}$ for each trail. The samples were kept at $20^{\circ} \mathrm{C}$. The power trail of 99 , and $77 \%$ corresponding to approximately 430 and $338 \mathrm{~W}$, respectively was used.

\subsubsection{Ho mogenization Index}

The homogenized milk was placed in to a graduated cylinder of $150 \mathrm{ml}$ and kept in a refrigerator for $48 \mathrm{hr}$. then the fat content of sample for the upper part, i.e. 1/10 (a) and from the bottom, i.e. 9/10 (b) of the graduated cylinder was determined by using the Gerber method[9]. The following equation was use to calculate the homogenization index (refer to reverse homogenization efficiency) $\eta_{h}$ of the sample $[8,10]$.

$$
\eta_{\mathrm{h}}=((\mathrm{a}-\mathrm{b}) / \mathrm{a})^{*} 100
$$

Where $a, b$, are the fat content of sample for the upper part and from the bottom

\subsubsection{D-value}

D-value was calculated from the following equation[11]:

$$
\mathrm{D}=\left(\mathrm{t}_{2}-\mathrm{t}_{1}\right) /(\log (\mathrm{c})-\log (\mathrm{d}))
$$

Where $\mathrm{c}$ and $\mathrm{d}$ represent the survivor counts following heating for $t_{1}$ and $t_{2}$ min, respectively. $D$ is the time needed to destroy $90 \%$ of the micro-organis ms (to reduce their numbers by a factor of 10) is referred to as the decimal reduction time or D-value.

\subsubsection{Microscopic Test}

The homogenized milk and control sample were showed by Bright-Field light microscope and effects for fat milk were noted.

\subsubsection{Total Bacterial Count}

The Standard Plate Count (SPC) gives an indication of the total number of aerobic bacteria present in the samples[12]. The original sample is diluted five times to decrease the bacteria numbers sufficiently. One $\mathrm{ml}$ fro $\mathrm{m}$ last two dilutions is then dispensed into a petri plate and incubated at $35^{\circ} \mathrm{C}$ for 24 hours and the pour plate method was carried out. All counts were expressed as (CFU/ml) of milk [12].

\subsection{Statistical Analysis}

One way ANOVA and post - hoc comparison statistical analyses which performed by using SPSS 11.0 statistical packages are applied [13].

\section{Results and Discussion}

\subsection{Homogenization Index}

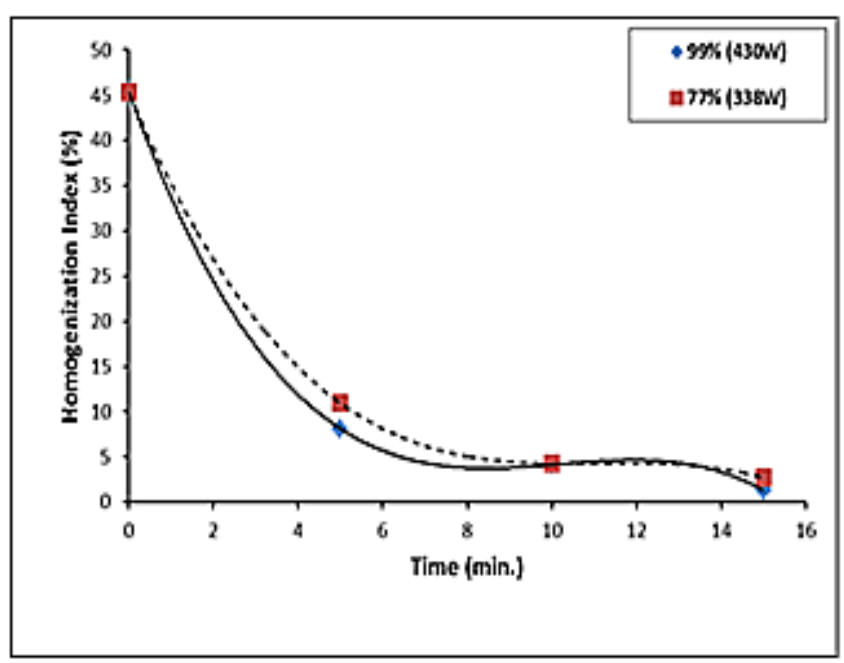

Figure 1. Homogenization index vs. time for different ultrasonic treatments

The homogenization index was significantly $(\mathrm{p}<0.05)$ reduced with increasing time at the power of 430 and 338 $\mathrm{W}$ (Fig. 1). The maximum homogenization index was in the control. Homogenization index was significantly $(\mathrm{p}<0.05)$ reduced with increasing time in the ultrsonic treatments. Reducing homogenization index that means high homogenization efficiency. A minimum homogenization index was 2 and $3 \%$ at $430 \mathrm{~W}$ and $338 \mathrm{~W}$ respectivily at 15 min.These results agree with Teknatext [10] who stated that homogenization must always be sufficiently efficient to prevent creaming. The result can be checked by 
determining the homogenization index. The index for homogenized milk should be in the range of 1 to $10 \%$. The impircal equations for calculating homogenization index $(\%)$ at $338 \mathrm{~W}$ and $430 \mathrm{~W}$ were:

$$
\begin{aligned}
& \eta_{\mathrm{H}(430 \mathrm{~W})}=-0.0427 \mathrm{t}^{3}+1.3053 \mathrm{t}^{2}-12.904 \mathrm{t}+45.333 \\
& \eta_{\mathrm{H}(338 \mathrm{~W})}=-0.0299 \mathrm{t}^{3}+1.0014 \mathrm{t}^{2}-11.134 \mathrm{t}+45.333
\end{aligned}
$$

Where $\mathrm{t}$ is the time (min.), $\mathrm{R}^{2}=0.999$ for eq. 1 and 2 .

\subsection{D-value}

The microbial destruction rate is generally defined in terms of a decimal reduction time (D-value) which is the heating time in minutes at a given temperature required to result in one decimal reduction in the surviving microbial population. In other words, D value represents a heating time that results in $90 \%$ destruction of the existing microbial population[11].

The mean $\boldsymbol{D}$-values were 6.47 and $5.49 \mathrm{~min}$. for ultrasonic treatments at 338 and $430 \mathrm{~W}$, respectively (Tab le 1). D-value was significantly $(\mathrm{p}<0.05)$ reduced with increasing time and power.

Table 1. D-values for different powers and times in the ultrasonic treatments

\begin{tabular}{ccc}
\hline \multirow{2}{*}{$\begin{array}{c}\text { time } \\
\text { (min. })\end{array}$} & \multicolumn{2}{c}{$\mathrm{D}(\mathrm{min})}$. \\
\cline { 2 - 3 } & $77 \%(338 \mathrm{~W})$ & $99 \%(430 \mathrm{~W})$ \\
\hline 5 & 7.63 & 7.95 \\
10 & 6.49 & 4.79 \\
15 & 5.29 & 3.75 \\
mean & 6.47 & 5.49 \\
\hline
\end{tabular}

\subsection{Effect of Ultras onic on B acterial Numbers}

Figure (2) illustrates the effect of ultrasonic on the numbers of bacteria in samples of buffalo milk and shows that the logarithms of numbers of bacteria were significantly $(\mathrm{p}<0.05)$ decreased with increasing power and increasing time of exposure compared with the control sample. The logarithms of the total numbers of aerobic bacteria after treatment directly were $(5.87$ and $4.71 \mathrm{CFU} / \mathrm{ml})$ when the powers were 388 and $430 \mathrm{w}$ respectively for a period of 15 minutes, and got increased by for storage where the logarith ms of the total numbers of bacteria on the sixth day became (7.04 and $7.08 \log \mathrm{CFU} / \mathrm{ml})$ at 388 and $430 \mathrm{w}$ respectively for a period of 15 minutes and the logarithms of the numbers of bacteria were ( 8.34 and 8.32 $\log \mathrm{CFU} / \mathrm{ml}$ ) at 388 and $430 \mathrm{w}$ respectively (Fig. 2-1).

The effect of ultrasonic treatment was evident in reduction of the logarithms of numbers of the coliform bacteria (Fig. 2-2) as the logarithms of numbers after treatment directly were (2.11 and $2.14 \log \mathrm{CFU} / \mathrm{ml}$ ) at 388 and $430 \mathrm{w}$ respectively for a period of 15 minutes compared with samples of control (3.64 and 3.08), respectively. Also, the staphylococci numbers were decreased compared with samples of control and the logarithms of numbers of bacteria were $(3.6$ and $3.8 \log \mathrm{CFU} / \mathrm{ml}$ ) at 388 and $430 \mathrm{w}$ respectively for a period of 15 minutes while the control samples had (4.19 and 4.17) at 388 and $430 \mathrm{w}$ respectively (Fig. 2-3).

Ultrasound causes cavitation's in aqueous solutions, which is an effective factor in damaging the cell wall of the micro-organisms, when a bubble collapses, a strong shear rate is generated in the environment that breaks the chemical bounds in the cells' wall and membranes[14]. The survival of Lactic acid bacteria was very low in very long exposures of ultras ound[15].

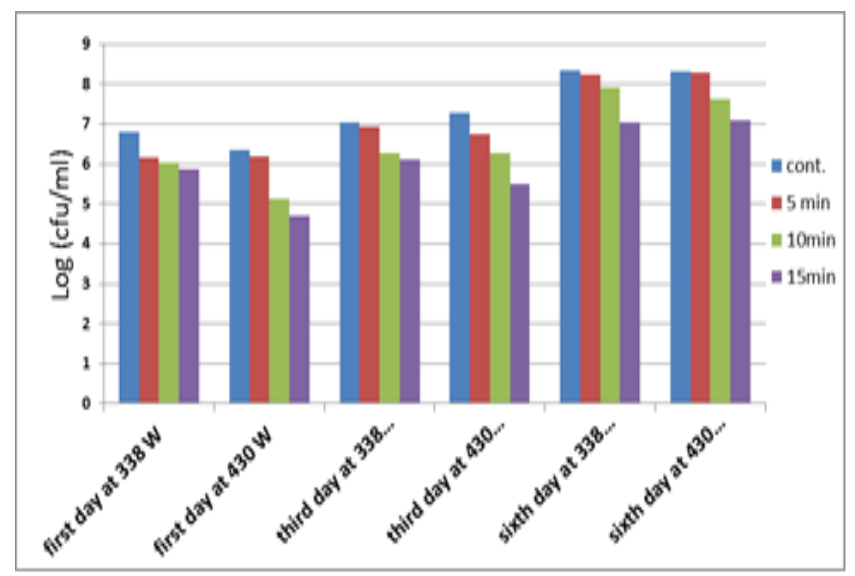

(a)

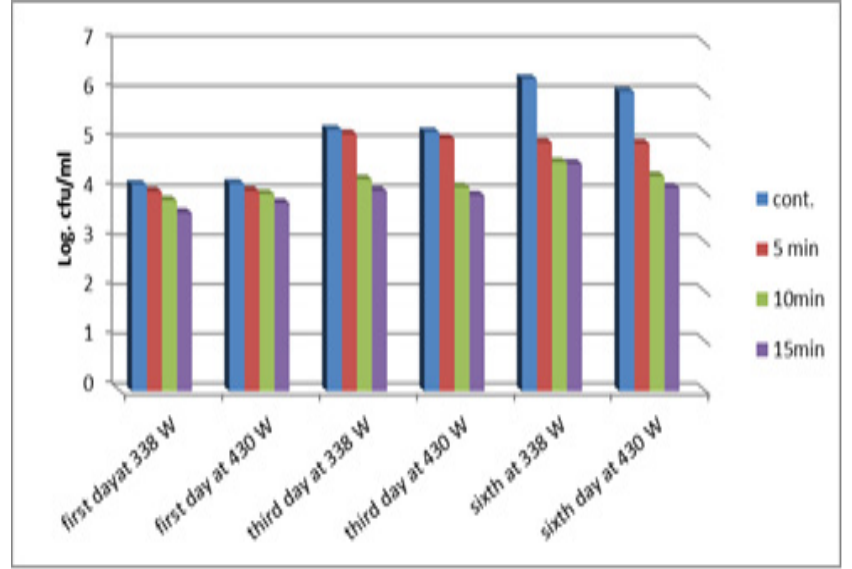

(b)

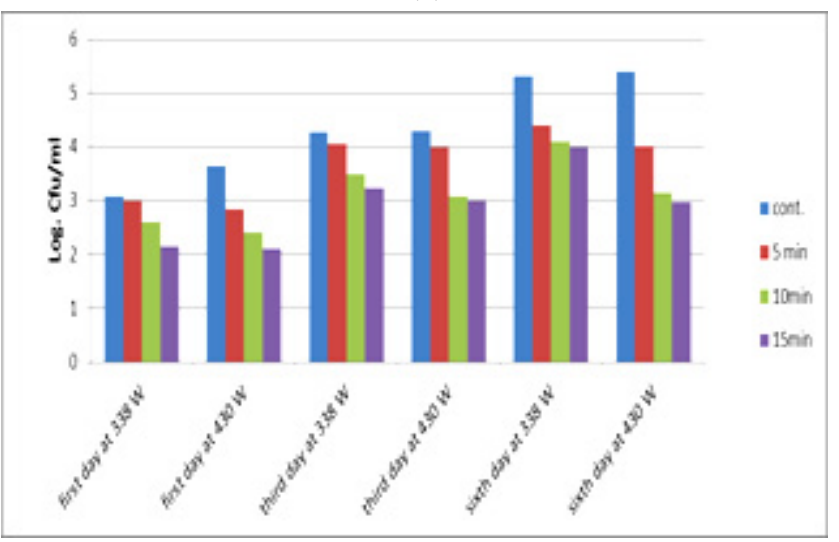

(c)

Figure 2. Log. number of bacteria of buffalo milk before of Ultrasonic treatment by ( $430 \mathrm{w}$ and $338 \mathrm{w})$ and during the period of storage (1, 3 and 6 days). (a): Log. of total bacterial count, (b): Log. of coliform bacteria and (c): Log. of staphylococci 


\subsection{Effect of Ultrasound on the Fat Globules}

Table 2. Percentage of fat directly after treatment and after 48 hour

\begin{tabular}{|c|c|c|c|c|}
\hline Treatments & Place & $\begin{array}{c}\text { Non } \\
\text { treatment }\end{array}$ & $\begin{array}{c}\text { Direct } \\
\text { after } \\
\text { treatment }\end{array}$ & $\begin{array}{l}\text { After } \\
48 \mathrm{~h}\end{array}$ \\
\hline \multirow{2}{*}{ Fresh milk } & Upper & 7.4 & & 7.5 \\
\hline & Lower & 6.4 & & 6.5 \\
\hline \multirow{2}{*}{$\begin{array}{c}338 \mathrm{~W} \text { at } 5 \\
\text { min. }\end{array}$} & Upper & & 7.5 & 7.5 \\
\hline & Lower & & 7.3 & 6.5 \\
\hline \multirow{2}{*}{$\begin{array}{l}338 \mathrm{~W} \text { at } 10 \\
\min .\end{array}$} & Upper & & 7.4 & 7.5 \\
\hline & Lower & & 7.3 & 7.0 \\
\hline \multirow{2}{*}{$\begin{array}{c}338 \mathrm{~W} \text { at } 15 \\
\text { min. }\end{array}$} & Upper & & 7.5 & 7.7 \\
\hline & Lower & & 7.4 & 7.5 \\
\hline \multirow{2}{*}{$\begin{array}{c}430 \mathrm{~W} \text { at } 5 \\
\text { min. }\end{array}$} & Upper & & 7.2 & 7.5 \\
\hline & Lower & & 7.0 & 6.9 \\
\hline \multirow{2}{*}{$\begin{array}{c}430 \mathrm{~W} \text { at } 10 \\
\mathrm{~min} .\end{array}$} & Upper & & 7.3 & 7.6 \\
\hline & Lower & & 7.1 & 7.3 \\
\hline \multirow{2}{*}{$\begin{array}{c}430 \mathrm{~W} \text { at } 15 \\
\min .\end{array}$} & Upper & & 7.1 & 7.3 \\
\hline & Lower & $\longrightarrow$ & 7.0 & 7.2 \\
\hline
\end{tabular}

Table (2) illustrates the percentage of fat directly after the treatment and after 48 hour. Ultrasonic treatment of milk produced buffalo milk with homogenized fat globules distributed uniformly in all parts of the sample. The percentages of fat in the upper layer of non -treatment sample was 7.4 and in the bottom of sample was 6.5 , but after $48 \mathrm{~h}$, the percentages of fat in the upper layer of non -treatment sample was 7.5 and in the bottom of sample was 6.5.The results showed the percentage of fat in the upper and bottom layers of homogenized milk samples by using
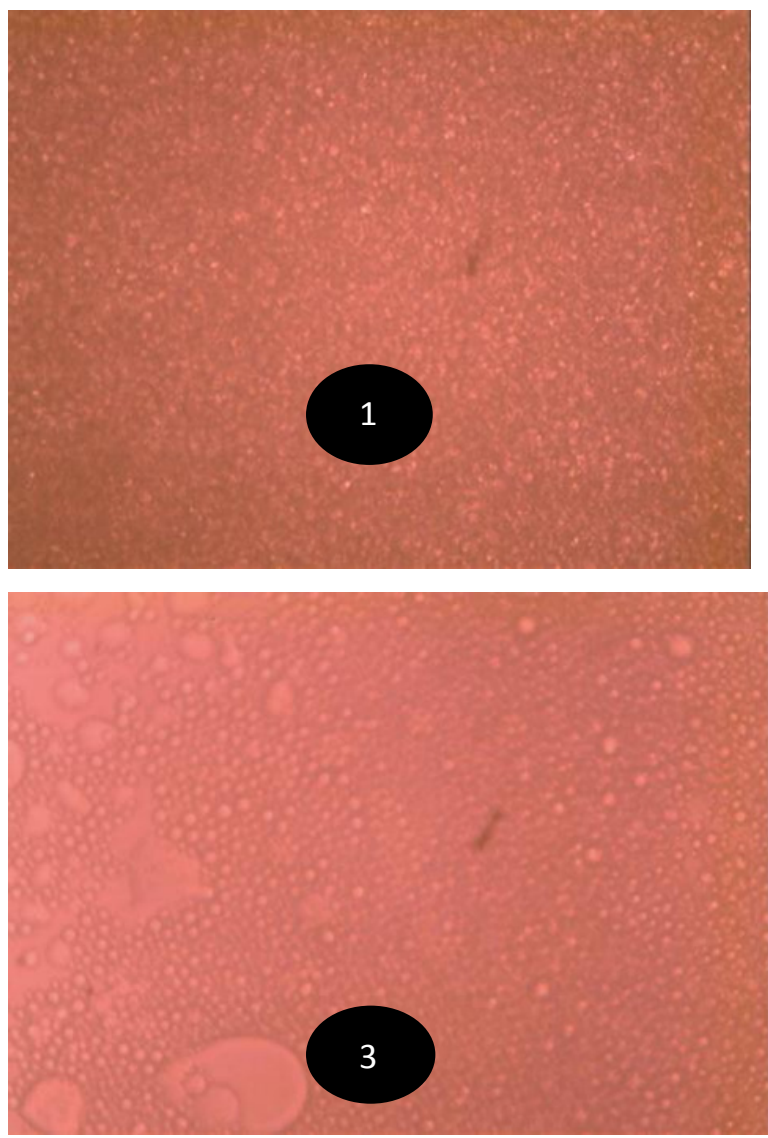

ultrasonic treatments were better than non-treatment samples, this due to ultrasonic treatments which causing of reducing of fat globule size. The homogenization of milk was significantly $(\mathrm{p}<0.05)$ increased with increasing power and time. This results agree with Luque and Priego [8] whose stated that ultrasound treatment with high amplitude (power) has an important effect on milk homogenization compared with conventional homogenization and the best homogenization and the smallest fat globule diameter $(0.725 \mu \mathrm{m})$ are obtained at a power level of 10 minutes.

\subsection{Effect of Ultras ound on the Fat Globules}

Figure 3 shows pictures of fat globules before and after ultrasound treatment and noted that the significantly $(p<0.05)$ increase in frequency and duration produces fat globules smaller Compared with non-homogenization sample (sample No. 1) and a sample at device homogenizer (sample No.8), The percentage of fat in the upper layer of the milk samples of no more than $10 \%$ for the bottom layer after 48 hours in all samples. Except for a sample of control and treatment $338 \mathrm{w}$ at $5 \mathrm{~min}$ (table-2). It can be concluded that ultrasonic treatment of milk produced buffalo milk and homogenized fat globules were distributed uniformly in all parts of the sample. The percentage of fat in the upper layer of non -treatment sample is 7.4 and 6.5 in low layer but after $48 \mathrm{~h}$ is $7.9,4.9$ respectively.
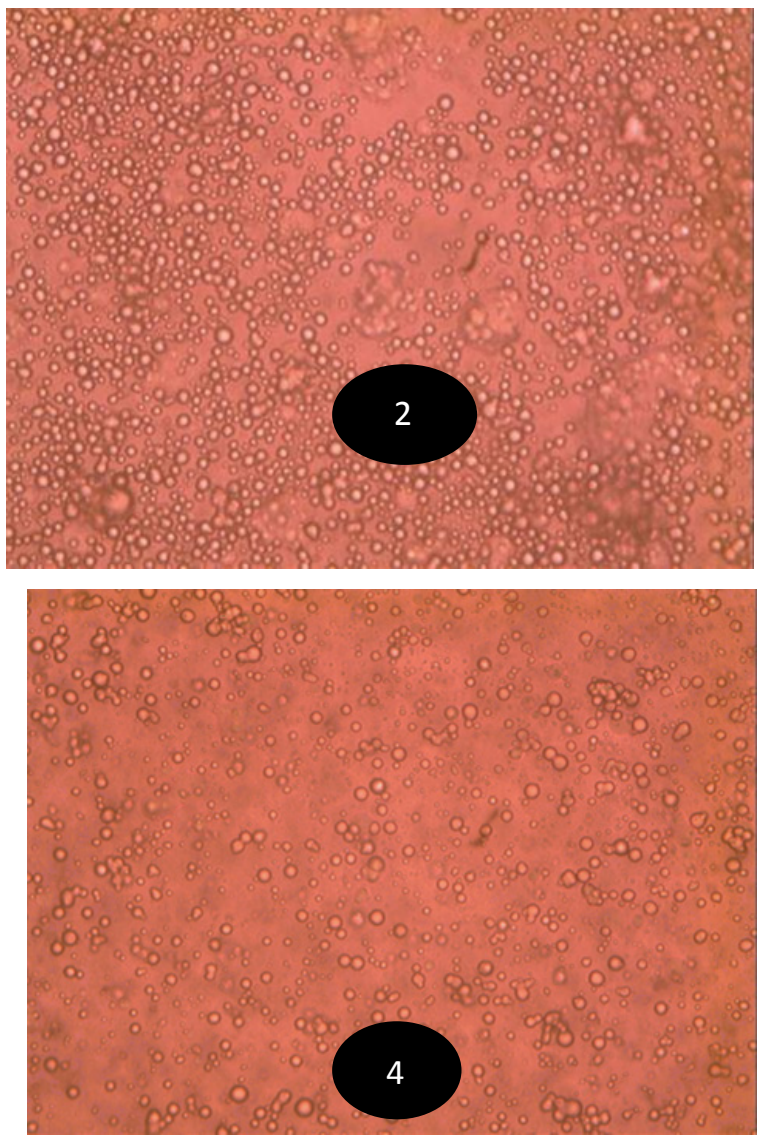

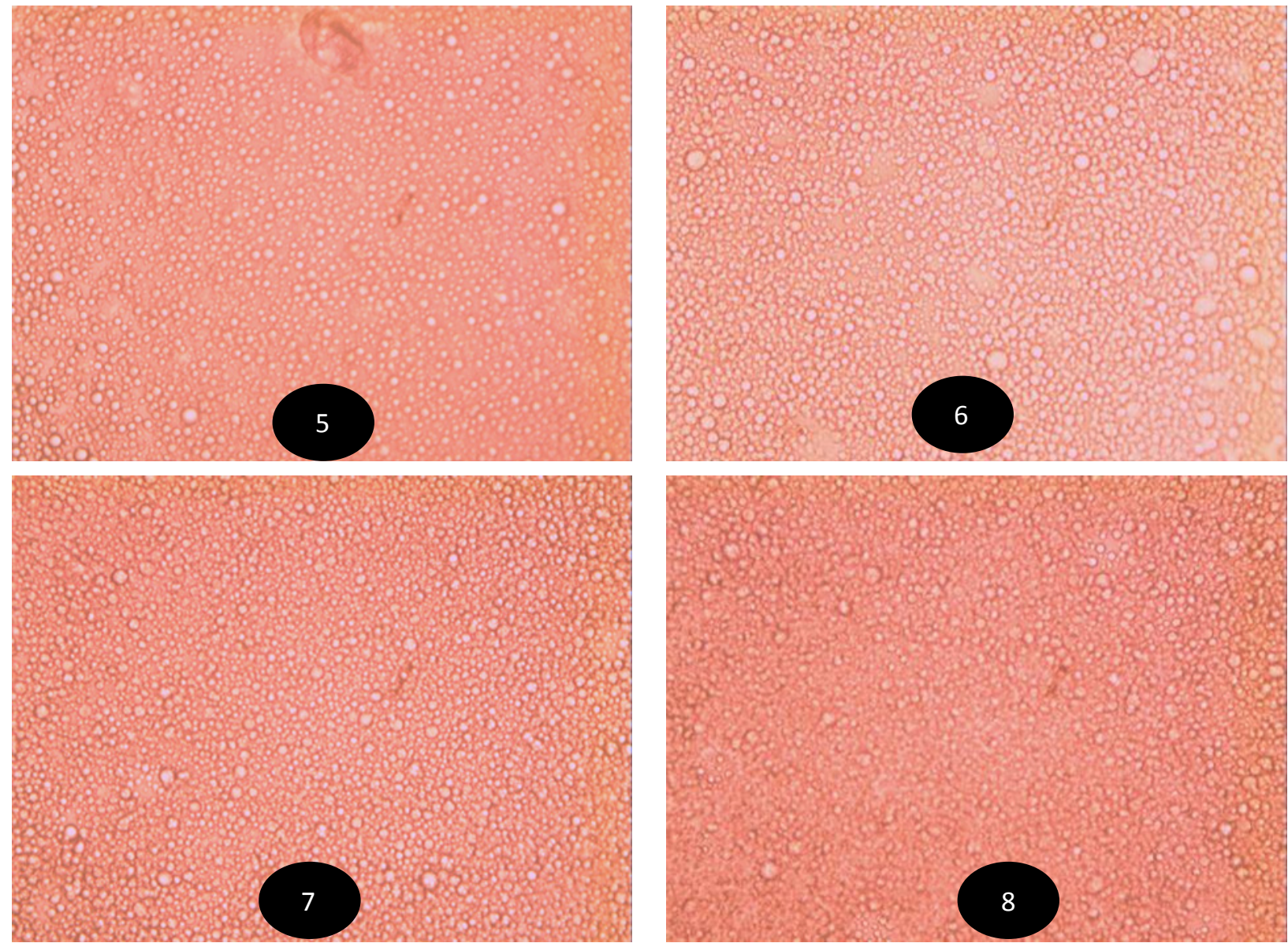

Figure 3. pictures fat granules before and after ultrasound treatment, (1) non treatment, (2) treatment on 338 w at $5 \mathrm{~min}$, (3) treatment on $338 \mathrm{w}$ at $10 \mathrm{~min},(4)$ treatment on $338 \mathrm{w}$ at $15 \mathrm{~min}$, (5) treatment on $430 \mathrm{w}$ at $5 \mathrm{~min},(6)$ treatment on $430 \mathrm{w}$ at $10 \mathrm{~min}$, (7) treatment on $430 \mathrm{w}$ at $15 \mathrm{~min}$, (8) treatment by homogenizer.

\section{Conclusions}

The obtained data from using ultrasonic treatments in the buffalo milk homogenization showed that the homogenization index was reduced with increasing time, and power. D-value was decreased with increasing time and power. The logarithms of numbers of bacteria were decreased with increasing power and increasing exposure to ultras onic compared with sample of control.

\section{REFERENCES}

[1] Cucheval, A. and R.C.Y. Chow. A study on the emulsification of oil by power ultrasound. Ultrasonics Sonochemistry, 15: 916-920. 2008.

[2] Letang C. , M. Piau , C. Verdier and L. Lefebure. Characterization of wheat-flour-water doughs: A new method using ultrasound. Ultrasonics, 39: 133-141. 2001.

[3] Villamiel M., E. H. Hamersveld and P. De.Van Jong. Effect of ultrasound processing on the quality of dairy products. Milchwissenschaft, 54: 69-73. 1999.

[4] Luque de Castro M.D. and F. Priego-Capote. Ultrasound assistance to liquid-liquid extraction: A debatable analytical tool. Analytica Chimica Acta, 583 :2-9. 2007.

[5] Pohlman, F. W., M. E. Dikeman, and J.F. Zayas. The effect of low-intensity ultrasound treatment on shear properties, color stability and shelf-life of vacuum-packaged beef semitendinosus and biceps femoris muscles. Meat Science 45: 329-337. 1997.

[6] Yuan Y., Y. Hu, T. Yue, T. Chen and Y. Martinlo. Effect of ultrasonic treatments on thermo acidophilic Alicy clobacillus acedoterrestris in apple juice. Journal of Food Processing and Preservation, 33: 370-383. 2009.

[7] Salmin O. , N. P. N. Salmin and D. A. Soly ankin. The patent of the Russian Federation 2104636 Milk 6 A01J11/16 The way of the production of high-fat milk products and the devices of its realization, appl. 26.04.96,publ. 21.01. 1997.

[8] Ertugay M.F., M., Şengul and Me., Şengul. Effect of ultrasound treatment on milk homogenization and particle size distribution of fat. Turkish Journal of Veterinary and Animal Sciences, 28:303-208. 2004.

[9] Bosiljkov T. , B.,Tripalo , M., Brni, M.,D., Ježek, S.,Karlovi and I.,Jagušt. Influence of high in-density ultrasound with different probe diameter on the degree of homogenization(variance) and physical properties of cow milk. African Journal of Biotechnology, 10: 34-41. 2011.

[10] Teknatext A. B.. Dairy Processing Handbook Tetra pak Processing systems AB . Lund Sweden , pp: 263 - 278. 1995. 
[11] Valentas, K.J., E. Rotstein and R.P. Singh. Handbook of food engineering practice. CRC Press, pp: 736. ISBN 0-8493-8694-2. 1997.

[12] Harley, J.P. and L.M. Prescott. Laboratory exercises in microbiology, 5th ed. The McGraw - Hill companies, U. S. A., pp: 01-106. 2002.

[13] SPSS. (2001). SPSS statistical package for windows. Ver.
11.0 Chicago:SPSS, Inc.

[14] Dubbs C. A.. Ultrsonic effects on isoenzymes. Clinical chemistry. 12:181-186. 1996.

[15] Tabatabaie F. and A. Mortazavi. Studying the effects of ultrasound shock on cell wall permeability and survival of some LAB in milk. World Applied Sciences Journal, 3: 119-121. 2008. 